
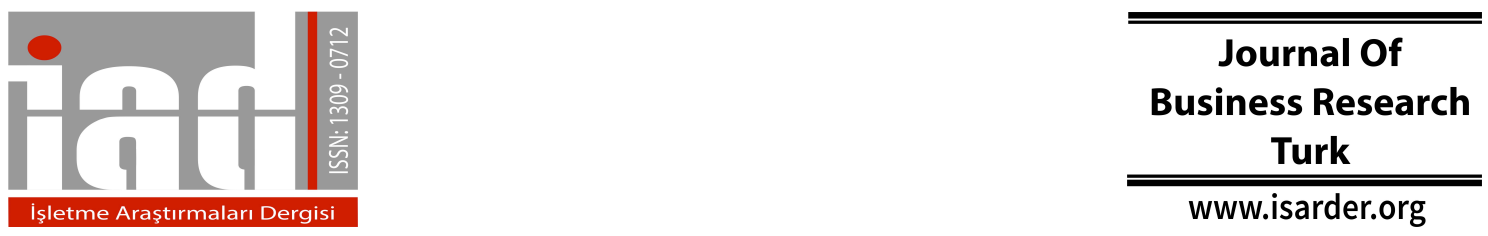

\title{
Internationalization Process and Entry Strategy of Turkish Furniture SMEs: Bursa-Inegol Sample
}

\author{
Javad ESMAEILI NOOSHABADI \\ Yalova University \\ Department of Business Administeration \\ Yalova, Turkey \\ orcid.org/0000-0002-6513-9850 \\ J.esmaeili67@gmail.com
}

\author{
Mehtap ÖZŞAHIN \\ Yalova University \\ Department of Business Administration \\ Yalova, Turkey \\ orcid.org/0000-0003-2527-4166 \\ mehtap.ozsahin@hotmail.com
}

\begin{abstract}
This paper examines the internationalization process of Turkish furniture small to medium-sized enterprises located in the Bursa-Inegol zone in terms of some wellknown theories of internationalization. Besides, the survey analyzes different types of entry mode used by furniture small to medium-sized enterprises in the international markets. Using qualitative exploratory approach, the results suggest that although the concept of psychic distance has been a significant issue for six investigated small to medium-sized enterprises, none of them followed the original Uppsala model. However, the Revised Model of Uppsala has been followed by four furniture cases. Moreover, the study illuminates that two investigated SMEs followed Born Global pattern of internationalization and two other SMEs followed the Born-again Global model. Besides, the results suggest that Turkish furniture small to medium-sized enterprises highly use direct export and partly indirect export modes for operating in the foreign markets.
\end{abstract}

Keywords: Internationalization Process of SMEs; Turkish Furniture Internationalization; International Entry Modes; Born Global companies; Uppsala and Revised Uppsala Model

\section{Introduction}

Furniture sector in Anatolia has exhibited traces from Mesopotamia and Hittite civilizations which were established in ancient age. Industrialization of furniture making in Turkey has begun in the 1970s (Serin et al., 2014). Today furniture sector in Turkey has become important knowledge and capital-intensive subsection by the production of $3 \%$ country manufacturing industry. The main reason for this transformation is emerging internationalization in the 1990s. With the increase in competition in these years, plants that produce at the economy of scale and world standards were established, which helped the furniture sector in Turkey to find a good position of selling products to both domestic and foreign markets (Serin et al., 2014). According to the Union of Chambers and Commodity Exchanges (2014), Turkey has around 1\% share of 146 billion dollars furniture market in the World. Moreover, Turkey is included among 5 
countries, which have had the most increased export ratio $(15 \%)$ in recent years. Accordingly, furniture sector in Turkey become one of the limited industry sectors with no foreign trade deficits since 2001 (TOBB, 2014).

According to the above discussion, Turkish furniture firms have had a significant growth in the foreign markets in the last decade which helped them to find a good position among the furniture market leaders in the world. The importance of issue has been an incentive for this study to explore and identify the process which is passed by Turkish furniture SMEs. As a consequence, the first and the main purpose of this study is to examine the internationalization process of Turkish furniture firms located in Bursa-Inegol region in terms of some well-known models of internationalization. Bursa is among the most efficient cities in the furniture manufacture sector by producing about $15 \%$ of total produced furniture in Turkey. It has a high development dynamics to become a significant global furniture center because of its potential geographical conditions. Geographical advantage such as its closeness to raw material resources and its location on the ancient Silk Road are two important properties that have facilitated development for furniture companies working in this region (TOBB, 2014). Although there have been done some studies about internationalization process of Turkish SMEs or firms (i.e. Erdil, 2012; Karabulut, 2013; Yilmaz et al., 2015; Kunday \& Sengüler, 2015; Bakar, 2014; Karadeniz \& Göçer, 2007), less is known about the internationalization process of Turkish furniture SMEs. For example, Yardibi (2016) recently explored the internationalization process furniture sector in Turkey. Yardibi (2016), focuses on the internationalization process which is passed by Turkish furniture companies in terms of just one theory of internationalization, namely Eclectic theory. Besides, he used quantitative approach by conducting questionnaire to 43 furniture companies. However, to add to the research literature, we conduct qualitative exploratory research by examining six cases of Turkish furniture SMEs internationalization. Besides, the current survey examines some other well-known models of internationalization rather than the Eclectic paradigm including the original Uppsala, the revised Uppsala, Born global, and Born-again global models. Moreover, the type of entry modes that Turkish furniture SMEs used to enter foreign markets will be explored. The process of deciding how to enter into international markets or selecting the right and appropriate entry mode strategy is a significant issue for all firms because it has a long-lasting impact on the success of a firm's international operations (Aulakh et al., 1998).

Based on the previous discussion, we develop the two following research questions. (1) "What entry mode strategy did Turkish furniture SMEs select during the process of internationalization?" (2) "How does the internationalization process look like for Turkish furniture SMEs?" This article adds to the literature by exploring the characteristics, strategies, and models of Turkish furniture SMEs internationalization by using six case studies in the context of Bursa-Inegol zone. The remainder of this paper is structured as follows. First, the survey provides an overview of the literature on the related issues of the internationalization process of SMEs include market entry modes for international businesses and some well-known models of internationalization. Then, it presents the research methods selected for this study. In the next part, the empirical findings resulted from an interview with six Turkish Furniture SMEs located in the Bursa-Inegol zone will be analyzed and discussed in relation to the reviewed literature. 
Finally, in the last part, conclusions and suggestions for further research will be provided.

\section{Literature Review}

\subsection{Market Entry Modes for International Businesses}

Exporting Modes: Exporting has been traditionally regarded as the first step to enter foreign markets, serving as a base for the future international expansions and developments (Kogut \& Chang, 1996). With Export entry modes, products are produced in the domestic market or in a third country and then transfer to the host market (Driscoll \& Paliwoda, 1997). Exporting modes considered being the most used strategies for SMEs because of their lack of resources (Dalli, 1995) and their limited degree of market knowledge or experience (Root, 1994). According to Hollensen (2007), exporting activities can take various forms including indirect export, direct export, and cooperative export marketing groups.

Contractual Modes: In this method, there is an agreement contract between a company and an agent, which based on that an agent produces and distributes the products in the international markets in return for some sort of economic rents (Kumar \& Subramaniam, 1997). Past Studies demonstrate that companies with standard product and high technology often use contractual agreement strategies (Datta et al., 2009). Generally speaking, this method is appropriate for firms that have some kind of competitive advantage over other firms but because of some constraints are not able to exploit them (Hollensen, 2007). Contract Manufacturing, Licensing, Franchising, Management Contracting, and Joint Venture (JV) are different types of this strategy.

Wholly Owned Subsidiaries: The concept of a subsidiary is not clearly defined in the literature. In practice, it refers to a company in which the parent company holds a majority of shares or other resources that are controlled. In the case where the subsidiary is $100 \%$ owned by the parent company is called a wholly-owned subsidiary. Otherwise, we talk about a joint venture subsidiary (Wach, 2014). For instance, a majority-owned (e.g., 75 percent) joint venture is a contractual entry mode strategy. However, similar to a hierarchical mode a company with $75 \%$ will have the full control (Hollensen, 2007). There are two ways to enter international markets by means of this strategy. The first one is "Acquisition" in which the parent company can obtain an established company in the host country and use that company for the promotion of its goods. The second one is "Greenfield venture" in which the parent company sets up a new operation in the host country (Hill, 2007).

\subsection{Theories of Internationalization}

Original Uppsala: Uppsala is a well-known behavioral model of internationalization, which has been claimed to be functional for many different companies and various conditions (Pedersen \& Petersen, 1998). According to Johanson $\&$ Associates (1994), there are four steps to internationalization. Sporadic or occasional export activities, exports through independent representatives or sale agents, the establishment of a branch or a sale subsidiary in the foreign country, and finally the establishments of a production unit in the foreign country (Johanson \& Associates, 1994). Another feature of the pattern is that internationalization frequently starts from foreign markets that are close to the domestic ones in terms of psychic distance, defined as factors that make it difficult to understand foreign environments. Factors such as 
distinctions between domestic and foreign markets in terms of political system, culture, and language (Johanson \& Associates, 1994). The companies then gradually enter other markets that are further away in terms of psychic distance (Johanson \& WiedersheimPaul, 1975). Therefore, firm's commitment increases gradually with knowledge accumulation. As a result, in this way firm can reduce the risk and uncertainty of operation in the international markets.

Revised Uppsala: The revised Uppsala model has two sides. First, markets are networks of relationships in which companies are linked to each other in a complex, different, and invisible patterns. Therefore, being a member of this network is an essential requirement for successful internationalization. Second, established relationship provide a potential for building commitment and for learning about the markets (Johanson \& Vahlne, 2009). As a result, the traditional view that firms internationalize by overcoming barriers and starting from countries with lower psychical distance has become less significant. Therefore, available network connections have a remarkable influence on the specific geographical location or market that a company will penetrate. Furthermore, since these business relationships enable firms to identify and exploit opportunities, they considerably impact managers' decisions on selecting various types of entry mode strategies in foreign markets. On the other hand, learning and commitment are strongly related to identifying opportunities. The firm by creating a heavy commitment to the network can gain access to the network information and knowledge and as a result, identify or create opportunities for itself. This knowledge is only told to the insiders of the network (Johanson \& Vahlne, 2009).

The answer to which market the company will choose is simply a market in which the company realizes more business opportunities. Therefore, there will not be a first step for the firm internationalization. However, if the company has no valuable partners, it may go where that is easier to find partners. These partners already have established relationships with local agents or distributors. Finally, when the company has established its own relationship with customers then it can bypass agents or distributors. In this condition, the short psychic distance will help the company to establish and develop its relationships with partners more quickly. Therefore, the short psychic distance will be a necessary but insufficient condition for the firm to exploit and identify opportunities (Johanson \& Vahlne, 2009).

Eclectic Paradigm: A critical assumption of this internationalization model is that international expansion can be described with respect to three factors: ownership advantages (O), location advantages (L) and internalization advantages (I) (Dunning, 1993). In addition to tangible assets, ownership advantage is also manifested by company particular ownership of intangible assets in compared to that of competitors (i.e. marketing knowledge, technological knowledge, or dominant managerial abilities) to coordinate and control its international transactions (Buckley \& Hashai, 2008). Internalization advantages refer to benefit of transferring the firm's ownership advantages abroad within the company's organizational structures (Dunning, 1988). The locational advantages relate to host country advantages such as market size, tax system, political conditions, infrastructure, education system, appropriate technology, labor availability and costs, geographical factors, and natural resources (Dunning, 1977). According to the OLI theory, firm's internationalization will be possible in the following way. First, the company must have ownership advantages over other domestic companies. If the firm could satisfy the first condition, then it can use its internalization 
advantages to exploit more competitive advantages over local companies in the international markets. If the firm could satisfy the two first conditions, it will be able to use foreign country resources, which are called locational advantages (Grillet, 2003). Therefore, this approach to internationalization suggests that these three factors must be present for international expansion of a firm (Bianchi, 2011).

Revised Eclectic Paradigm: Dunning later redefined and extended the subject matter of the OLI paradigm to cover all value-creating activities, not just international production exclusively. Therefore, Dunning (1988), added alternatives for FDI in his Model. With this change, Dunning provided a broader model of internationalization, which is a severe break with the former formulations of the paradigm (Pederson, 2003). According to the model, internationalization can be done through FDI by building a subsidiary in the host country; internationalization can be done through export by some agents or distributors; or internationalization can be done by arrangements that need some level of close collaboration between two or more parties (contractual agreements) such as joint ventures, co-production, or licensing. Dunning proposes that export or trade mode replaces with direct investment mode when there is no locational advantage. However, it is interesting that Dunning admits the presence of internalization advantages, meaning that there are some advantages to keeping control over the distribution channel through export mode. The only possible interpretation is that Dunning thinks of export by means of a sales subsidiary in the importing country. In cases where there is neither I advantages nor L advantages, contractual resource transfer by franchising, licensing, or other sorts of bilateral agreements (Pederson, 2003).

Born Global: According to the definition, a born global company is a business organization that seeks to acquire superior performance in the international markets from the application of knowledge-based resources to the sale of outputs in multiple countries, from or near the inception (Knight \& Cavusgil, 2004). Besides, the concept of born-again global companies has been presented more recently. This concept involves companies that worked for a long time in the domestic markets, but they suddenly entered foreign markets and internationalized at a great speed (Bell et al., 2001). However, for the born global firms the time that the firm passes from the local foundation to the first entry in the international markets is fewer than three years (Autio et al., 2000). Normally, the number of employees in these firms is less than 500 and the annual sales are under $\$ 100$ million. Their reliance is on producing and developing unique and innovative products through cutting-edge technologies (Hollensen, 2007). Even though these companies compared to the large international firms are lack of resources, but their advantage rests on learning from alliance network relationships (Contractor, 2007). They often built partnerships in the form of hybrid structures (licensing, franchising, or joint ventures) to overcome their lack of experiences (Oviatt \& McDougall, 1994). Another factor related to the born global firms is that often founder, owner, or CEO operates the company and makes the decisions personally. Therefore, because of their flexible operating procedures, Born Global firms can react more rapidly than established firms when confronting with various market conditions (McDougall \& Oviatt, 1997).

\section{Methodology}

This study employs a multiple case study approach (Yin, 2014) focusing on six Turkish furniture SME located in the Bursa-Inegol zone. Using a case study approach 
the survey try to develop further insights, to gain a more in-depth approach into how the internationalization of these SMEs occurs, and also to determine whether internationalization theories apply to the furniture SMEs. This approach should assist in advancing our understanding of the internationalization of SMEs and the finer details about how they embrace their internationalization process, what entry mode they use, and how this compares with the other SMEs or firms in other industry sectors. Besides, the purpose of this research would mainly be exploratory. Exploratory research is related to a phenomenon that we do not have enough knowledge or information about, such as an undiscovered or new subject, which only a few studies already have been conducted about it (Yin, 2003). By using exploratory elements, which are the interview with owners of furniture SMEs and the review of the related literature, the study tries to draw a better picture of the internationalization process of Turkish furniture SMEs.

The qualitative research approach was adopted because it is appropriate when the researchers have no previous understanding of the phenomenon (Bogdan \& Taylor, 1987). As a result, through qualitative approach researchers can achieve a closer observation of the behavior of a firm (Firestore, 1993), discover the true inner meaning and new knowledge about it (Zikmund \& Babin, 2010), and thereby describe, decode, and translate a certain naturally occurring phenomenon in the social world (Van Maanen, 1983). Therefore, the selected qualitative research approach helped authors to provide a deeper understanding of the internationalization process of Turkish furniture SMEs. According to Silverman (1993), there are four qualitative methods: observation, analyzing texts, interview, and recording and transcribing. Three of them were used for the current research including observation, interview, and recording and transcribing.

This study uses both primary and secondary data gathering methods for collecting data to provide better answers to the research questions. First, research started by reviewing and collecting secondary data about internationalization process of the firms from related journals, websites, and books. Then, primary data was collected by conducting face to face interviews with owners and managers of furniture SMEs that already had a presence in international markets. The gathered data from the interviews and the complementary data extracted from the secondary resources enabled the authors to identify, understand and analyze the internationalization process of investigated SMEs within the international markets.

The interview questions were divided into two parts: First, respondents were asked to provide information about the profile as well as the growth of their SMEs in the international markets. For this section, a table was designed including four parts: the name of the countries that the firm entered, year of the entry to those countries, type of the first entry mode adopted for each country, and finally, changes in the operation modes during the later stage of internationalization. The table enabled the authors to explore more accurately the process of internationalization which is passed by the six furniture case studies. The second part was related to the internationalization specific questions. All of these questions were designed open-ended in order to participants feel free at the time of answering questions. The interviews were audio recorded, transcripted, and translated from Turkish to English.

It would be superlative to use the whole population in every type of research to gather data, however, often it is impossible because of some restrictions. In practice, external factors such as time and financial resources may limit the collection of 
information (Robson, 2002). Because of these restrictions, this study used convenience sampling technique for selecting eligible furniture SMEs. Eisenhardt (1989), suggests that four to ten cases are enough to provide material for analysis. For this study, six Turkish furniture SMEs were targeted that geographically were near and accessibility to the owners of those SMEs was convenient. These case studies were selected according to the following criteria: (1) Turkish furniture SMEs located in Bursa-Inegol zone. (2) Turkish furniture SMEs which are already internationalized and have a presence in foreign markets. Selected SMEs are coded from C1 to C6. Interviews were conducted with the owners and managers of these six SMEs. Owners are the most relevant source of information for the researched area since they are directly involved in the decisionmaking process regarding the export activities of the SMEs. Respondents' length of work in the furniture SMEs varies from 7 to 19 years. This indicates that they had enough experience to satisfy the objectives of this study.

Table 1. Profile of six furniture SMEs

\begin{tabular}{|c|c|c|c|c|c|}
\hline $\begin{array}{c}\text { Name Of } \\
\text { The Firm }\end{array}$ & $\begin{array}{c}\text { Year Of } \\
\text { Foundation }\end{array}$ & $\begin{array}{c}\text { Year Of } \\
\text { Internationalization }\end{array}$ & $\begin{array}{c}\text { Number of Full- } \\
\text { Time Employees }\end{array}$ & $\begin{array}{c}\text { Foreign } \\
\text { Sales/Total } \\
\text { Sales Rate }\end{array}$ & $\begin{array}{c}\text { Number of } \\
\text { Foreign } \\
\text { Markets }\end{array}$ \\
\hline C1 & 2007 & 2011 & 23 & $10 \%$ & 1 \\
\hline C2 & 2005 & 2008 & 140 & $25 \%$ & 5 \\
\hline C3 & 1964 & 2002 & 28 & $40 \%$ & 11 \\
\hline C4 & 2004 & 2009 & 35 & $40 \%$ & 10 \\
\hline C5 & 2004 & 2007 & 65 & $35 \%$ & 15 \\
\hline C6 & 2009 & 2009 & 30 & $100 \%$ & 15 \\
\hline
\end{tabular}

Source: Interview (2016)

As this survey only investigated six case study organizations, we argue that this is not generalizable to the population of Turkish furniture SMEs which internationalize; however, we do argue that our results display analytical generalization (Yin, 2014) where our results can be compared and generalized against theories in the area.

\section{Analysis and Discussion of the Findings}

Entry Mode: Deciding how to enter target markets has been a critical issue for SMEs because different entry modes have different consequences for them. Turkish furniture SMEs used highly direct export and sporadically indirect export modes for operating in foreign countries. Four out of six SMEs only used direct export as the first entry strategy including C2, C4, C5, and C6 SMEs. Therefore, the managers of these SMEs preferred to make direct contact with foreign customers and distributors. Besides, the owner of C1 SME chose indirect export as the first mode. These five SMEs had no change in the operation modes in later stages. However, C3 SME started internationalization using the indirect export from Greece and in the later stage added direct mode. For other markets, C3 SME mainly used direct export. Furthermore, investigated furniture SMEs had not any kind of Foreign Direct Investment (FDI) activity in international markets. 
Table 2. Internationalization of Six Turkish Furniture SMEs

\begin{tabular}{|c|c|c|c|}
\hline $\begin{array}{l}\text { Name of } \\
\text { The Firm }\end{array}$ & International Markets & $\begin{array}{l}\text { Type of the First } \\
\text { Entry Mode }\end{array}$ & $\begin{array}{l}\text { Changes in } \\
\text { Operation Mode } \\
\text { in Later } \\
\text { Stages }\end{array}$ \\
\hline $\mathrm{C} 1$ & Azerbaijan (2011) & Indirect Export & No change \\
\hline $\mathrm{C} 2$ & $\begin{array}{c}\text { Azerbaijan (2008); Libya (2008); Saudi } \\
\text { Arabia (2008); UAE (2008); Algeria (2008) }\end{array}$ & Direct Export & No Change \\
\hline $\mathrm{C} 3$ & $\begin{array}{l}\text { Greece (2002); Kosovo (2002); Albania } \\
\text { (2002); Jordan (2003); Iraq (2003); Iran } \\
\text { (2004); Austria (2005); Israel (2005); } \\
\text { Azerbaijan (2010); Libya (2010); } \\
\text { Kazakhstan (2011) }\end{array}$ & $\begin{array}{c}\text { Indirect \& } \\
\text { Direct Export }\end{array}$ & $\begin{array}{l}\text { Change From } \\
\text { Direct to } \\
\text { Indirect or the } \\
\text { Reverse for } \\
\text { Some Countries }\end{array}$ \\
\hline $\mathrm{C} 4$ & $\begin{array}{c}\text { Iraq (2008); Iran (2010); Azerbaijan (2011); } \\
\text { Jordan (2011); Algeria (2011); Macedonia } \\
\text { (2013); UEA (2014); Austria (2014); Oman } \\
\text { (2015); Israel (2015) }\end{array}$ & Direct Export & No Change \\
\hline $\mathrm{C} 5$ & $\begin{array}{c}\text { Azerbaijan (2007); Jordan (2008); Iraq } \\
\text { (2010); Libya (2010); Oman (2010); } \\
\text { Kosovo (2011); Bulgaria (2012); Saudi } \\
\text { Arabia (2013); Algeria (2013); UAE } \\
\text { (2013); Georgia (2013); Germany (2013); } \\
\text { Palestine (2014); Belgium (2015); France } \\
\text { (2015) }\end{array}$ & Direct Export & No Change \\
\hline C6 & $\begin{array}{c}\text { UAE (2009); Iran (2009); Azerbaijan } \\
\text { (2009); Libya (2010); Germany (2010); } \\
\text { France (2010); Swiss (2011); Netherland } \\
\text { (2011); Austria (2011);Saudi Arabia } \\
\text { (2011); Oman (2012); Belgium (2012); } \\
\text { Georgia (2012); Jordan (2012); Israel } \\
\text { (2015) }\end{array}$ & Direct Export & No Change \\
\hline
\end{tabular}

Source: Interviews (2016)

\subsection{Theories of Internationalization}

Original Uppsala: Based on the original Uppsala or the stage internationalization model, SMEs gradually expand their operations and commitment to foreign markets by acquiring knowledge and experience. They start the process by sporadic export, then use direct export, then establish a foreign sales subsidiary, and finally produce products in the foreign markets (Johanson \& Associates, 1994). This has not been the case for six investigated Turkish furniture SMEs. All SMEs only used direct and indirect export modes that are considered as the first and the second stages of the Uppsala model, and they did not increase their commitment further in the international markets. Besides, the six SMEs not only used experiential knowledge but also some other methods in order to gather data and information about potential foreign markets opportunities. For all cases, attending in the network relationships seems to be the most valuable source of acquiring knowledge. Some managers also discussed that they acquired related knowledge from valid furniture publications and magazines $(\mathrm{C} 2$; $\mathrm{C} 4)$. Therefore, results are not in line with the study conducted by Johanson \& Vahlne (1977) that argues the right way of gaining market knowledge is just by learning from experiences step by step. 
Moreover, the stage model argues that internationalization often begins from foreign countries which are near to the local country especially in terms of the psychic distance. The companies would then gradually enter other markets with greater psychic distance (Johanson \& Wiedersheim- Paul, 1975). This process seems to be true to a high extent for Turkish furniture SMEs investigated in this study. The regional markets such as Azerbaijan, Iran, Arab countries, Greece, Kosovo, and Albania were the first choices of the Turkish furniture SMEs. In addition to the proximity of those countries to Turkey, Azerbaijan and partly Iran share a similarity in language. Besides, the culture of Turkey has similarity with that of Arab countries, Iran, Azerbaijan, and some other neighbor countries. After entering short psychic distance countries, then four SMEs (C1; C2; C3; C4) gradually started their exports to other markets that were further away in terms of psychic distance such as Belgium, France, Germany, Swiss, and Netherland. Although the concept of psychic distance has been important for six furniture SMEs, the process stopped in the first and second steps of internationalization provided by the original Uppsala model. The results are in the same line with Forsgren (2002) findings that the model is only applicable at the first stages of the internationalization process. As a consequence, the original model of Uppsala does not entirely support internationalization process of investigated SMEs. Similarly, Sullivan and Bauerschmidt (1990), concluded that the empirical evidence does not support the model, after testing the incremental internationalization hypothesis. Recently, one study has been done about Internationalization Process of Turkish SMEs by Karabulut (2013) that claims Turkish SMEs internationalize gradually as it is explained in the original Uppsala theory. Therefore, the result is against to the findings of the current study.

Revised Uppsala: The revised model of Uppsala highlights the importance of network relationships in business activities. Therefore, firms will go abroad based on their relationships with important domestic or foreign partners who are committed to developing the business through internationalization (Johanson \& Vahlne, 2009). Through these relationships, companies are able to find business opportunities as well as access to existing knowledge in the network. Business relationships have been very important for the growth of investigated Turkish furniture SMEs in foreign markets. They tried to build more relationships either by their personal activity or by becoming a member of local associations in order to access more opportunities for export. According to the owners and managers of six furniture SMEs, they made their personal relationships mostly by meeting their foreign counterparts in the international furniture fairs or exhibitions. Manager of C6 SME believed that travels to different countries also helped him to build strong relationships with foreign partners. Moreover, four from six companies were a member of IMOS (Inegol Mobilya Sanayicileri Dernegi) including C2, C3, C4, and C6 SMEs. Another association was ICCI (Inegol Chamber of Commerce and Industry) that C1, C2, C3, and C5 SMEs had the membership. There are other important local unions, which SMEs have participated such as Inegol Young Businessmen Association, Istanbul Exporters Union, Industrial Trade Center of Turkey, and Independent Industrialist and Businessmen Association. According to the owner of C4 SME, the most important advantage of network relationships has been the guaranteed annually economic growth. C6 SME's owner argued that access to the valuable information about markets and customers' needs has been the most important benefit of networks for the company development. Manager of C3 SME shared the same opinion that the business relationships provided them significant information and knowledge about the new foreign market opportunities. Manager of C5 SME said that 
through network relationships they could learn about the types of products that they should produce.

According to the revised model of Uppsala, companies will choose their partners where they see opportunities from market to market. Thus, there will not be the first step of internationalization as the original model discussed (Johanson \& Vahlne, 2009). As a result, based on this model the importance of psychic distance and entry mode for choosing new foreign markets become less significant than the past. However, authors of the model (Johanson \& Vahlne, 2009) discuss that if a firm has no valuable partners in domestic or foreign markets, it may go where that is easy to connect with final customers. Therefore, in this situation, the short psychic distance will facilitate the establishment and development of relationships, which is a necessary but insufficient condition for identification and exploitation of opportunities (Johanson and Vahlne, 2009). This can be true for four cases of the sample study (C1; C2; C3; C4). They firstly started internationalization from short psychic distance markets such as neighbor countries and later developed their activities to both countries with short and long psychic distance. For example, in 2002, C3 SME exported its products to Greece, Kosovo, and Albania, which are the northwestern neighbors of Turkey. Soon after in 2003, it increased its presence in other markets, like Jordan and Iraq the Southern neighbors. In 2004, C3 SME entered to market of Iran, another country with similarity in culture and to some extent language. However, in 2005, the SME started activity in further away countries such as Austria and Israel. After five years in 2010, it entered Azerbaijan, which is close to Turkey in terms of its culture and language. Finally, C3 SME engaged in Kazakhstan a northwestern neighbor of Turkey in 2011. C4 SME started internationalization from neighbor countries such as Iran, Iraq, and Azerbaijan. Later the SME entered the market of countries with longer psychic distance such as UAE, Austria, Oman, and Israel. The first export activity of C5 SME was to Azerbaijan, a neighbor country with high similarity in language. Other neighbor countries were Iraq, Kosovo, and Bulgaria. However, C5 SME later increased its international activities to countries with greater psychic distance such as Germany, Belgium, and France. C6 SME started internationalization from neighbor countries such as Iran and Azerbaijan and then exported to further away countries such as Swiss and Netherland.

Therefore, at first, these four SMEs had no strong position in the network. They started internationalization from countries with more proximity to Turkey in terms of language, culture, and geographical distance. Then, when they found a stronger position in the networks they entered into further away markets, where they would see more opportunities such as Germany, France, Austria, Swiss, and so on. It seems that the other two furniture SMEs $(\mathrm{C} 1 ; \mathrm{C} 2)$ did not follow opportunities in the further away markets because they still are working in the first markets they entered.

Eclectic Paradigm: The main assumption of the original Eclectic or OLI model is that Foreign Direct Investment (FDI) can be explained by satisfying three variables, which are Ownership, Location, and Internalization advantages (Dunning, 1977). By FDI companies will have more control on the markets, thus, they will be able to perform their programs in the way they like. However, furniture cases had not any kind of Foreign Direct Investment (FDI) activity in other countries. Some managers argued that Turkey itself is an appropriate place for foreign companies to conduct FDI. The owner of C1 SME stated that since Turkey is a fast developing country with a large market size, low rent, low energy expenses, and particularly a rich source of raw material, thus it is a 
suitable country for the FDI. Manager of C6 SME expressed that they will start FDI only if a foreign country can provide a better condition for investment than Turkey. Therefore, results do not support the original eclectic paradigm of internationalization.

Revised Eclectic Paradigm: In the original Eclectic paradigm, the model only addresses one particular form of internationalization, namely FDI. However, in the new model, eclectic theory extended to cover other alternative entry modes such as export and contractual agreements. According to the model, internationalization can be done by FDI if three kinds of ownership, location, and internalization are prepared for companies (original model). When firms have ownership and internalization advantages they can go foreign markets through export mode by means of a sales subsidiary in the importing country. When the company only possesses ownership advantage, internationalization can be done by contractual agreements such as licensing, franchising, and joint venture (Pederson, 2003). Even though the six furniture SMEs used direct and indirect export modes, however, they had not any sales subsidiary in foreign markets. For example, $\mathrm{C} 1$ manager selected indirect export entry mode. C2 owner chose direct export entry mode to engage in five foreign markets with no changes in the operation modes during the later stages. For C3 SME exports are conducted through two modes: directly through a domestic distributor or indirectly through agents who are working in Turkey. C4, C5, and C6 SMEs entered international markets directly with importers or distributors, while domestic agents are not commonly used. Besides, they did not use other types of entry modes suggested in the model such as export and contractual agreements. Therefore, the revised eclectic model also does not support internationalization process of the furniture SMEs. As a result, the finding of this study is in the same line with Dunning's argumentation (1988) that the paradigm has little predictive power for individual firms. Findings support results provided by Karabulut (2013) that Turkish SMEs have focused more on exporting than other modes of internationalization.

Born Global: According to the definition, a firm can be Born Global or international new venture if the firm pursues a vision of becoming a global actor rapidly from or near its inception without any preceding long-term domestic operation (Knight \& Cavusgil, 2004; Oviatt \& McDougall, 1994). Some studies (Autio et al., 2000; McDougall \& Oviatt, 2000), argue that for Born Global Companies the period from domestic establishment to first foreign market entry is often fewer than three years. $\mathrm{C} 1$ and $\mathrm{C} 2$ SMEs started their internationalization four and three years after their inception, but then the process stopped in the first markets. C3 SME began foreign activity 38 years after working in the domestic markets but then had a rapid growth in 11 countries from 2002 to 2011. C4 SME started internationalization 5 years after foundation and exported its products to 10 countries with a fast rate from 2008 to 2015 . C5 SME engaged internationalization after 3 years working in the domestic market. The speed of internationalization has been faster for $\mathrm{C} 5 \mathrm{SME}$ by the presence in 15 foreign markets from 2007 to 2015 . Finally, C6 SME is the only case that had not any domestic activity and started internationalization right from the inception. C6 SME has the fastest speed rate of internationalization among six furniture SMEs by activity in 15 international markets from 2009 to 2015.

Reliance on cutting-edge technology in the development of a relatively unique product is another characteristic of Born Global firms (Hollensen, 2007). Findings of this study show that even though the investigated furniture SMEs produce various 
ranges of products, they mostly focused on specific furniture sectors. The specific characteristic that facilitated the process of internationalization for six examined furniture SMEs has been the quality of their products. According to the owner of $\mathrm{C} 1$ SME, innovation in production was another important factor. For C2 and C6 SMEs, based on their managers' view, products' design was important. According to managers of $\mathrm{C} 3, \mathrm{C} 4$, and $\mathrm{C} 5$ furniture SMEs, the competitive price of products has been a significant factor for penetrating into international markets. These facts show that furniture SMEs' managers are aware of the importance of global niche markets.

Another significant factor of Born Global firms as a business organization is that they tend to be managed by entrepreneurial visionaries of owners (Hollensen, 2007). According to the managers, the personal characteristics that led them toward international markets were entrepreneurial abilities of owners such as risk-taking and self-reliance. Besides, based on founders of C3 and C5 SMEs, sociability or the ability to connect via social networking was an important personal factor. This factor motivated them to connect with more foreign partners and make a stronger relationship with them. According to the owners of $\mathrm{C} 2, \mathrm{C} 4$, and C6 SMEs, they also have tried to be innovative in furniture markets, and thus manufacture products based on the needs and the desires of customers.

In the Born Global companies, often CEOs or owners make the decisions personally (McDougall \& Oviatt, 1997). The owner of C1 SME told the decisions that he made were not influenced by associations. Five other furniture SMEs' managers also argued that associations have not necessarily influenced their decisions. However, they said that they may change their decisions based on the information provided by associations or unions. Therefore, there is no organizational routine or internal politic to influence managers' decisions. Moreover, Born Global firms can be characterized by being SME with less than 500 employees (Hollensen, 2007) and with more than 25\% foreign sales revenue from total sales rate (Kuivalainen et al., 2007). All of the six furniture SMEs that were examined had less than 500 employees. The foreign sales revenue for $\mathrm{C} 1, \mathrm{C} 2, \mathrm{C} 3, \mathrm{C} 4, \mathrm{C} 5$, and $\mathrm{C} 6$ were $10 \%, 25 \%, 40 \%, 40 \%, 35 \%$, and $100 \%$, respectively.

Based on the all above factors and characteristics that are discussed, it seems that C5 and C6 SMEs followed Born Global pattern of internationalization. On the other hand, findings also indicate that the internationalization process seems to be Born-again Global for C3 and C4 SMEs because they worked in the domestic markets for a long time and then suddenly had a rapid internationalization. The internationalization process of the other two furniture SMEs $(\mathrm{C} 1$; $\mathrm{C} 2)$ followed by stagnation. Besides foreign sales revenue for $\mathrm{C} 1 \mathrm{SME}$ was less than $25 \%$. Therefore, they are not considered being conformed to Born Global or Born-again Global theories of internationalization.

\section{Conclusion}

This study investigated the internationalization process and the type of entry mode strategies that Turkish furniture SMEs used to enter foreign markets in the sample of six case studies located in the Bursa-Inegol region. The main purpose of this survey was to describe how Turkish furniture SMEs located in this region internationalized. Since little attention has been devoted to the internationalization of SMEs in Turkey, this study tried to fill this gap by providing a better understanding of the phenomenon. Moreover, less is known about the internationalization process of Turkish furniture SMEs. 
This research shows that Turkish furniture SMEs highly used direct export and sporadically indirect export mode for operating in foreign countries. Furthermore, investigated furniture SMEs had not any kind of Foreign Direct Investment (FDI) activity. They also did not use Contractual or Wholly Owned Subsidiaries in foreign markets. Besides, survey results reveal that although the concept of psychic distance has been important for six furniture SMEs, none of them followed the stage model of internationalization (Uppsala). However, the Revised Model of Uppsala is applicable for four furniture SMEs including C3, C4, C5, and C6. At first, these four SMEs had no strong position in the network, therefore, they began internationalization from countries with more proximity to Turkey in terms of language, culture, and geographical distance. Then, when they found better and stronger position in the networks they entered other markets with greater physical and psychical distance such as Germany, France, Austria, and Swiss. Findings also demonstrate that Eclectic (OLI) paradigm did not follow by SMEs because the sample furniture cases had not any FDI activity. Besides, they did not have any plan for FDI in foreign markets. The Revised Eclectic model of internationalization also is not applicable to furniture companies because they had not any sales subsidiary in foreign markets. Furthermore, they did not use other types of entry modes suggested in the model such as contractual agreements. Survey illuminates that two furniture SMEs, C5 and C6, followed Born Global pattern of internationalization because they pursued a vision of becoming a global actor rapidly from or near their inception without long-term domestic operation. On the other hand, two other SMEs, C3 and C4, followed the Born-again Global model because they worked for a long time in the domestic markets and then suddenly had a rapid internationalization.

The scope of this study is limited to the internationalization process of six Turkish furniture SMEs located in the Bursa-Inegol zone. There are other highly internationalized furniture SMEs in other cities of Turkey such as Istanbul, Izmir, Ankara, and Kayseri. It would be interesting to investigate furniture SMEs in these cities to find out whether there is any difference between internationalization process them and furniture SMEs located in the Bursa. Besides, this survey is conducted on furniture SMEs in Turkey, a developing country. In a developed country the internationalization process of SMEs may differ. Moreover, in any other industry, the same research may reveal different results. So, it would be better to repeat this survey on SMEs operating in other industries, in developed countries, and in under-developed countries.

Last but not least, internationalization is a broad concept that can be influenced by unlimited factors. That's why different kinds of theories have emerged. This study just explored some well-known theories of internationalization including Uppsala, revised Uppsala, Eclectic, revised Eclectic, Born Global, Born-again Global. However, there is no one single accepted theory, which describes and demonstrate the internationalization process of all companies. Further research may also investigate other theories of internationalization for internationalization process of Turkish furniture SMEs. 


\section{REFERENCES}

Alvesson, M. \& Deetz, S. (2000). Doing Critical Management Research, Sage Publications Ltd., London.

Andersson, S. (2000). The Internationalization of the Firm from an Entrepreneurial Perspective. International Studies of Management \& Organization, 30(1), 63-92.

Aulakh, P. S., Cavusgil, S. T., \& Ghoshal, S. (1998). Compensation in International Licensing Agreements. Journal of International Business Studies J Int Bus Stud, 29(2), 409-419.

Autio, E., Sapienza, H.J. and Almeida, J.G. (2000). Effects of Age at Entry, Knowledge Intensity, and Imitability on International Growth. Academy of Management Journal, 43(5), 909-924.

Bell, J., McNaughton, R. and Young S. (2001). Born-Again global firms: an extension to the born global phenomenon. Journal of International Management, 7(3), 173190.

Bogdan, R. And Taylor, S. (1987). Looking at the bright side: A positive approach to qualitative policy and evaluation research. Qualitative Sociology. 13 (2), 183192.

Contractor, F. J. (2007). Is international business good for companies? The evolutionary or multi-stage theory of internationalization vs. the transaction cost perspective. Management International Review, 47, 453-475.

Czinkota, M. R., \& Ronkainen, I. A. (2009). Global marketing: Foreign entry, market development \& strategy implementation. Toronto: Nelson Education.

Dalli, D. (1995). The organization of exporting activities: Relationships between internal and external arrangements. Journal of Business Research, 34(2), 107-115.

Datta, D. K., Liang, X., \& Musteen, M. (2009). Strategic Orientation and the Choice of Foreign Market Entry Mode. Management International Review Manag Int Rev, 49(3), 269-290.

Denscombe, M. (2003). Good research guides for small-scale social research projects. 2. ed. Maidenhead, Phil.: Open University Press.

Driscoll, A. M., \& Paliwoda, S. J. (1997). Dimensionalizing international market entry mode choice. Journal of Marketing Management, 13(1-3), 57-87.

Dunning, J. H. (1977). Trade, Location of Economic Activity and the MNE: A Search for an Eclectic Approach. The International Allocation of Economic Activity, 395-418.

Dunning, J. H. (1988). Explaining international production. London: Unwin Hyman.

Dunning, J. H. (1993). Multinational enterprises and the global economy. Wokingham: Addison-Wesley.

Eisenhardt, K. M. (1989). Building Theories from Case Study Research. Academy of Management Review, 14(4), 532-550.

Erdil, S. (2012). An Analysis of Internationalisation Behavior of Firms through Activities and the Case of Turkish Firms. International Strategic Management Conference, 58(2012), 1247-1255. 
Firestore, W. (1993). Alternative Arguments for Generalizing from Data as Applied to Qualitative Research. Educational Researcher, 22(4), pp. 16-23.

Gartner, W. B. (1988). "Who is an Entrepreneur?" Is the Wrong Question. Entrepreneurship as Organizing, 25-46.

Gluckler, J. (2005). A relational assessment of international market entry in management consulting. Journal of Economic Geography, 6(3), 369-393.

Grillet, M. (2003). Internationalization towards China after its Accession to the WTO. Are There Opportunities for European SMEs? (Unpublished master's thesis, 2003). Katholieke Universiteit Leuven.

Hill, C. W. (2007). International Business: Competing in the global marketplace. Boston: McGraw-Hill/Irwin.

Hollensen, S. (2007). Global marketing: A decision-oriented approach. Harlow: Financial Times Prentice Hall.

Johanson, J. \& J.-E. Vahlne, "The Mechanism of Internationalization", International Marketing Review 7 (1990), pp.11-24, as publicized in Johanson \& Associates, 1994, pp.84-95.

Johanson, J., \& Mattson, L.G. (1988). Internationalization in industrial systems: A network approach In Hood, N., Vahlne, J-E., (eds), Strategies in global competition. Croom Helm, London, 194-213.

Johanson, J., \& Vahlne, J. (1977). The Internationalization Process of the Firm-A Model of Knowledge Development and Increasing Foreign Market Commitments. Journal of International Business Studies J Int Bus Stud, 8(1), 23-32.

Johanson, J., \& Vahlne, J. (1990). The Mechanism of Internationalisation. International Marketing Review, 7(4).

Johanson, J., \& Vahlne, J. (2009). The Uppsala internationalization process model revisited: From liability of foreignness to liability of outsidership. Journal of International Business Studies J Int Bus Stud, 40(9), 1411-1431.

Johanson, J., \& Wiedersheim-Paul, F. (1975). The Internationalization Of The Firm? Four Swedish Cases. J Management Studies Journal of Management Studies, 12(3), 305- 323.

Jones, M. V., and Coviello, N. E. (2005). Internationalization: Conceptualizing an entrepreneurial process of behavior in time. Journal of International Business Studies, 36, 284-303.

Karabulut, A. T. (2013). Internationalization of Turkish SMEs: An Empirical Study. International Journal of Business and Management, 8(6), 2013th ser., 68-88.

Knight, G.A., \& Cavusgil, S.T. (1996). The born global firm: A challenge to traditional internationalization theory. Greenwich, CT.

Knight, G.A., and Cavusgil, S.T. (2004). Innovation, organizational capabilities, and the born-global firm‘, Journal of International Business Studies, 35(2): 124-141.

Kogut, B., \& Chang, S. J. (1996). Platform Investments and Volatile Exchange Rates: Direct Investment in the U.S. by Japanese Electronic Companies. The Review of Economics and Statistics, 78(2), 221. 
Kumar, V., \& Subramanian, V. (1997). A contingency framework for the mode of entry decision. Journal of World Business, 32(1), 53-72.

Madsen, K. T. \& Servais, P. (1997) The internationalization of Born Globals: an evolutionary process. International Business Review, 6 (6), 561-583.

Moen, O. (2002). The Born Globals. A new generation of small European exporters. International Marketing Review, 19 (2), 156-175.

Mort, G. S. and Weerawardena, J. (2006) Networking capability and international entrepreneurship. How networks function in Australian born global firms. International Marketing Review, 23, 549-572.

Oviatt, B. M., \& Mcdougall, P. P. (1994). Toward a Theory of International New Ventures. Journal of International Business Studies J Int Bus Stud, 25(1), 45-64.

Oviatt, B. M., and McDougall, P. P. (1997). Challenges for internationalization process theory: The case of international new ventures. Management International Review, 37 (2), 85-99.

Pedersen, K., (2003). The Eclectic Paradigm: A New Deal? Journal Of International Business And Economy, 14-26.

Pedersen, T., \& Petersen, B. (1998). Explaining gradually increasing resource commitment to a foreign market. International Business Review, 7(5), 483-501.

Reynolds, P., Bosma, N., Autio, E., Hunt, S., Bono, N. D., Servais, I., Chin, N. (2005). Global Entrepreneurship Monitor: Data Collection Design and Implementation 1998?2003. Small Bus Econ Small Business Economics, 24(3), 205-231.

Robson, C. (2002). Real world research: A resource for social scientists and practitioner-researchers. Oxford, UK: Blackwell.

Root, F. R. (1994). Entry strategies for international markets. New York: Lexington Books.

Root, F. R., \& Root, F. R. (1987). Entry strategies for international markets. Lexington, MA: Lexington Books.

Serin, H. et al. (2014). Furniture sector of Turkey. International Association of Social Science Research, 2(6), 147-151.

Sharma, D.D., \& Blomstermo, A. (2003). The internationalization process of Born Globals: a network view. International Business Review, 12(1), 739-753.

Silverman, D. (1993). Interpreting qualitative data: Methods for analyzing talk, text, and interaction. London: Sage Publications.

The Turkish Furniture Products Assembly Sector Report (pp. 1-74, Rep. No. 2014/212). (2014). Iskitler, Ankara: Afşaroğlu Matbaası. the Union of Chambers and Commodity Exchanges of Turkey (TOBB).

Van Maanen, J., (1983) Qualitative Methodology, Sage Publications.

Wach, K. (2014). Market Entry Modes for International Business (chapter 7). In: E. Horská (Ed.). International Marketing: Within and Beyond Visegrad Borders. Kraków: Wydawnictwo Episteme, 135-147.

Yardibi, C. (2016). Mobilya Sektöründe Uluslararasılaşma Ve Rekabet Stratejileri: Türkiye Örneği (Unpublished master's thesis). Türk Hava Kurumu Üniversitesi. 
Yin, R. K. (2009). Case study research: Design and methods. Los Angeles, CA: Sage Publications.

Yin, R.K., (2003). Case Study Research: Design \& Methods. 3rd ed. Thousand Oaks: Sage Publications Inc.

Zikmund, W. G., \& Babin, B. J. (2010). Essentials of marketing research. Mason, OH: South-Western/CENGAGE Learning.

Âijö, T, Kuivalainen, O. Saarenketo, S., Lindqvist, J. and Hanninen, H. (2005) Internationalization Handbook for the Software Business, Centre of Expertise for Software Product Business, Espoo, Finland. 